\title{
DIFFERENCE ANALYSIS OF MODERN MARKET AND TRADITIONAL MARKET STRATEGY BASED ON LAYOUT AND QUALITY OF SERVICE
}

\author{
Nel Arianty* \\ Lecture of Economic Faculty, Muhammadiyah University of North Sumatra, Medan, Indonesia \\ DOI: http://dx.doi.org/10.24327/ijrsr.2017.0803.0071
}

\section{ARTICLE INFO}

\section{Article History:}

Received $15^{\text {th }}$ December, 2016

Received in revised form $25^{\text {th }}$

January, 2017

Accepted $28^{\text {th }}$ February, 2017

Published online $28^{\text {th }}$ March, 2017

\section{Key Words:}

Modern Market, the Traditional Market, the Layout, And The Quality Of Service

\begin{abstract}
This study aimed to compare the traditional markets and modern markets in terms of the layout and quality of service. The results of this study will be useful for governments and agencies involved in the development of traditional markets, and can make improvements in terms of the layout and quality of service. At the end of the traditional market will demand back by consumers. This research uses descriptive quantitative research approaches as well as differences in test consumer perceptions of traditional and modern market in terms of layout and quality of service. The result of differences in the perception of consumers in terms of layout showed a significant difference between the traditional and modern market with a probability value of 0.000 . The next test of differences in the perception of consumers in terms of quality of service shows that the probability value has 0.000 , which means that there is a significant difference between service qualities modern markets and traditional markets. From the results of the performance matrix plotting known that the modern market analysis service quality assessment factors more are in quadrant $\mathrm{B}$, which is to be maintained, followed by quadrants $\mathrm{A}$ and 2-factor in quadrant C. For service quality factor of traditional markets, 17 factors are in quadrant $\mathrm{D}, 1$ factor are in quadrant $\mathrm{C}$. modern market perceived service quality by consumers, while the traditional market is considered quite good.
\end{abstract}

Copyright (C) Nel Arianty, 2017, this is an open-access article distributed under the terms of the Creative Commons Attribution License, which permits unrestricted use, distribution and reproduction in any medium, provided the original work is properly cited.

\section{INTRODUCTION}

Economic growth and development of the region will be affected by a number of system activities, one of which is trade. One indicator of the level of progress in the economic field visits of the frequency of activity in the trade sector. Trading activity will always require facilities that include office space with adequate infrastructure and facilities to accommodate the event. The market is one of the facilities for the trading activity.

The market is a meeting place for a number of buyers and sellers where the number of transactions happening goods there. Based on how the transaction market is divided into traditional markets and modern markets. The traditional market is a place where buyers and sellers can conduct bargaining directly and traded goods are staple goods. While in the modern market, goods are traded at fixed prices and with the service itself. An example is the mall, supermarket. The market has always been a focus point of a city that serves as a center for exchange of goods. In a city, the market stems from a set of vendors selling wares in groups by choosing strategic locations, which later evolved.
The existence of a modern market in Indonesia is experiencing rapid growth. According to data, hypermarket is a retailer with growth rates the highest (25\%), cooperatives (14.2\%), minimarket / convenience stores $(12.5 \%)$, Independent Grocers $(8.5 \%)$ and supermarkets (3.5\%), (Anonymous, 2010). In Indonesia, there are 13,450 traditional markets with approximately 12.6 million small traders and based on study results A.C. Nielsen, modern market in Indonesia grew $31.4 \%$ per year, while the traditional market shrinking $8 \%$ per year (Smeru, 2007). The existence of modern market like mushrooms in the rainy season is a threat to the existence of traditional markets.

In the middle of the emergence of the modern market, the traditional market still has a loyal fan. Especially those who are still very pleased with the hospitality and the high social interaction. Things that could still make traditional markets survive. A system of bargaining for some people is a challenge that fun is the main attraction, than when shopping at fixed prices. However, in addition to bearing the natural advantages, the traditional market has many weaknesses that have become the basic character very difficult to change. Factor market design and appearance, atmosphere, layout, diversity and quality of the goods, sales promotion, market limited operating 
hours, as well as optimizing selling space utilization is the biggest drawback of traditional markets in the face of competition from modern market.

Findings from qualitative methods showed that the main cause of losing its competitive traditional markets and supermarkets is poor management and poor infrastructure of traditional markets and not solely because of the presence of supermarkets. Supermarket actually taking advantage of the bad conditions that exist in traditional markets (Smeru, 2007).

The layout is different from the traditional markets of the modern market. The modern market more regularly so as to make consumers feel comfortable shopping, with unnecessary price negotiable, and self-service systems that make customers serve themselves. Private ownership of the modern market is a factor that allows all matters described previously. While a traditional market trader contains a bunch of different backgrounds make it difficult to organize and direct them. Structuring traditional markets are not too regularly leads consumers prefer shopping in the modern market. Not to mention the bargain is sometimes used by traders to give too high a price. The complexity of the issues and differences between the traditional and modern markets are very significant over time make traditional markets abandoned by consumers.

For all the problems it is necessary to examine the differences between traditional and modern market, for further analysis so as to improve the bargaining position of the traditional market. The assessment will be carried out from the side of the layout and quality of service in the traditional markets and modern markets.

\section{Theoretical Framework}

Until now, although the traditional markets provide various needs of society at a cheap price, but the traditional market is still synonymous with inadequate environmental management system as well as the bad. In line with the development of an increasingly modern world, many people began to leave things the traditional round switch to something more modern. It is seen one of them on today's consumer behavior is more like shopping in modern market than traditional market. That is because the quality of the goods traded in modern markets better with packaging and low prices. Besides the atmosphere in the modern market is more comfortable so that consumers more flexibility to choose the goods needs.

According to Engel, F et al (2001) suggest determinant decision on selection of stores varies by market and by product class. Attributes striking / determinants usually fall into the following categories (1) the location; (2) the nature and quality of diversity; (3) price; (4) Advertising and Promotion; (5) sales personnel; (6) the services provided; (7) the physical attributes of the store; (8) the nature of the customer; (9) the atmosphere and store (10) service and satisfaction after the transaction.

Teller and Reutterer (2008) grouping related matters or retail market appeal that can affect perception in the shop, among others:

1. Location, namely the distance between the location of the residence market, area of parking and accessibility to the market.

2. Merchants and products, which guarantee the fulfillment of the needs of consumers.

3. Environment, the cleanliness and comfort.
4. Market appeal is one form of market competition. According Fox and Sethuraman (2006), there are some things that are in the dimension of market competition, the prices of goods, the diversity and availability of products as well as the location of the market.

The traditional market is the market where the sellers and buyers bargaining directly resulting in a price agreement between the two sides. Toya (2012) explains that the traditional market is a place to sell the products of basic needs generated by economic actors medium and small, such as farmers, fishermen and craftsmen domestic industry so that the traditional markets have an important role in employment on the local community.

Traditional markets tend to have poor physical condition. But for consumers who are still loyal, traditional market still has its own charm. No appeal to the traditional market is a cheaper price, the price is negotiable, the location of which is usually close to where you live, plenty of food and fresh produce as well as providing all the needs, especially the daily needs of the community.

In the modern market is not going direct interaction between consumers and traders. According Witz and Whitfield (2006), basically a modern market to attract consumers by offering the ambience pleasant, good service and a diverse variety of goods under one roof. Meanwhile, according to Subandi (2005) in the Devi (2012), modern market has advantages in the application of the concept of professionalism and k Quality of service to attract consumers as much as possible so that the design layout of the building since its inception has been to consider the alignment and comfort, with parking provision, space convenient, easy access to public transportation, sorting of goods and services from the saleswoman very indulgent consumers.

Disclosed by Thang and Tan (2003) things that can influence consumer behavior is the image of the store, including merchandise, store ambience, service in the store, accessibility, promotion, reputation, support facilities and services after the transaction. This shows that the support facilities are available in the market is important.

Consumer behavior is divided into two, namely the perception of an object as a form of interpretation and preferences as the tendency of choice in things. In an election, there are things that are taken into consideration. By Salvatore (2006), consumer preferences expressed on several assumptions used as the colonies in consumer preferences are as follows:

1. The taste of an individual does not change during a certain period.

2. The consistency, i.e. when the consumer is observed more than an object like the object $\mathrm{A}$ is $\mathrm{B}$ then the consumer will never love object objects B than A.

3. The existence of transitivity, i.e. if $\mathrm{A}$ is preferred to B and $\mathrm{B}$ is preferred to $\mathrm{C}$, then $\mathrm{A}$ is preferred to $\mathrm{C}$.

4. Consumers may be encouraged to buy any combination of goods if the price is made sufficiently attractive.

The location of the market, according to Fox and Sethuraman (2006), is one of the things that are considered traders as the cause of market competition. Market place associated with 
consumer convenience, and the distance that the market is close to the consumer is considered more convenient for consumers. Distance between traditional stores and modern store locations that are within a range of services will affect consumer preferences in deciding where to shop.

There are two potential factors that could affect the choice of location shopping, i.e. the size of the store and the distance between the location of the consumer's home store. It supported the statement Melvin Grennhut were found when the price elasticity of demand infinite, markets tend to be located at a place consumer (Djojodipuro, 1992).

Parasuraman, Zeithaml \& Berry (1990) stated that the quality of service is a fundamental strategy in an effort to achieve a successful service manager. Things underlying quality of service are the dimensions that can be used to evaluate the quality of service regardless of the type of services. According to Zeithaml, Parasuraman, Berry (1990). To know the quality of service perceived by the consumer significantly, there are indicators that measure consumer satisfaction lies in the five dimensions of service quality. Servqual fifth dimension that includes the following:

1. Tangibles (quality of service in the form of physical infrastructure of offices, computerized administration, a lounge area and place information). This dimension relates to the modernity of the equipment used, the appeal of the facilities, personnel neatness and completeness of the supporting equipment (pamlet, announcements).

2. Reliability (ability and reliability to provide a reliable service). Dimensions related to the promise of getting things the way she wanted, the handling of consumer complaints, the performance of appropriate services, rendering of services promised time and improving demands on recording errors.

3. Responsiveness (willingness to assist and provide services quickly and accurately, as well as responsive to the desires of consumers). This dimension includes the notification from the clerk to the consumers on the services to be provided, service delivery quickly, the willingness of officers to give assistance to the consumer and the clerk never felt busy to serve consumer demand. Assurance (capabilities and the friendliness and courtesy of staff in ensuring consumer confidence). This dimension relates to the behavior of officers who remain confident that consumers feel safe going to the ability of officers and can answer consumer questions.

4. Empathy (firm but caring attitude from the clerk to the consumer). This dimension contains, among others, giving individual attention to consumers, timeliness of services for all consumers; companies have officers who give special attention to the consumer, the consumer services to be provided and the officer who understands the specific needs of its customers.

If the perceived performance exceeds expectations, the customer will be satisfied. Customers are happy and content tend to behave positively. Customers form an expectation of the value and the action they take into account and evaluate the bids, which would give it high marks. Special meeting the expectations of customer value affects customer satisfaction and the possibility of buying back (Parasuraman, 1998).

According to Philip Kotler-performance analysis of the significance of (importance-performance analysis) can be used to rank the various elements of a collection of services and identify the actions required. Martilla and Jams in (Zeithaml et al, 1990) suggests the use of methods Importance-Performance Analysis to measure the level of satisfaction of services. In this method required the measurement of conformance to find out how much customers are satisfied with the performance of the company, and how big the service providers understand what customers to the services they provide.

In the analysis Importance-Performance Analysis, mapping into four quadrants for all the variables that affect the quality of service.

Strategies that can be made with regard to the position of each variable on the four quadrants can be explained as follows:

1. Quadrant 1 (Concentrate Reviews These): This is the area that includes the factors that are important to customers, but in fact these factors have not been in line with expectations of customers (satisfaction level obtained is still low). The variables included in this quadrant must be improved.

2. Quadrant 2 (Keep Up The Good Work): This is the area that includes the factors that are considered important by customers, and the factors that are considered in accordance with the customer already feels so relatively higher levels of satisfaction. The variables included in this quadrant must be maintained for all these variables make a superior product or service in the eyes of the customer.

3. Quadrant 3 (Low Priority): This is the area that includes the factors that are considered less important by customers, and in fact the performance is not too special. Increasing the variables included in this quadrant may be reconsidered because of its effect on the benefits perceived by the customer is very small.

4. Quadrant 4 (Possible Overkill): This is the area that contains factors are considered less important by customers, and felt too much. The variables included in this quadrant can be reduced so that companies can save costs.

\section{RESEARCH METHODOLOGHY}

This research is located in the city of Medan. The population in this study is the traditional and modern markets in the city of Medan. Given the limited capacity, cost, effort and time owned and allocated to researchers, the sample set is the traditional market is the Simpang Limun Market and modern market is located in Plaza Hypermart Palladium. Due to limited number of researchers, the number of samples, namely consumer users traditional and modern markets are set respectively as many as 50 people, by way of sampling was accidental sampling.

Data was obtained through interviews with consumers of traditional and modern market. To questions related to consumer perception of service quality and layout of the modern and traditional markets. Data on quality of service and perception of the layout of the market were collected by spreading questionnaire to consumers of traditional markets 
and modern markets as respondents. The instrument is tested for validity and reliability.

Data analysis techniques in this study using data analysis techniques quantitative descriptive and comparative with the tools:

Importance-Performance Analysis, useful for analyzing the average level of interest relevant attributes and the level of performance of the company and as a guide in allocating resources to the organization that is limited to specific areas, where improvements in performance can have a major impact on total customer satisfaction. Besides this matrix can also show specific fields or attributes that need to be maintained and aspects that need to be reduced priority.

The formula used is:

NIK $_{\text {importance }}$ atribute $\mathrm{i}=\frac{\sum(N j \cdot X i)}{\sum k}$
NIK $_{\text {performance }}$ atribute $\mathrm{i}=\frac{\sum(N j . X i)}{\sum k}$
$\overline{\overline{X_{1}}}=\frac{\sum_{i=1}^{n} \bar{X}_{i 1}}{k}$ dan $\quad \overline{\bar{Y}}=\frac{\sum_{i=1}^{n} \bar{Y}_{i 1}}{k}$

Where:

$\mathrm{k} \quad$ : the number of instruments

NIK : the value of the performance index

$\mathrm{Nj} \quad$ : score (very dissatisfied/very unimportant $=1$, not satisfied/not important $=2$, satisfied/important $=3$, very satisfied/very important $=4$ )

$\mathrm{Xi} \quad$ : respondents

To measure the difference in consumers' perceptions of traditional markets and modern markets (in terms of both quality of service and layout), using independent sample t-Test, as it aims to analyze the average difference in the two groups are not related one another. With the following criteria a. Reject $\mathrm{HO}$ if the calculated probability value $\leq$ specified probability or [Sig (2-tailed) $\leq \alpha 0.05]$

b. Accept $\mathrm{HO}$ if the calculated probability value $>$ specified probability or [Sig (2-tailed) $>\alpha 0.05]$

\section{FINDINGS AND DISCUSSION}

\section{Analysis of Performance Matrix Modern Market Analysis}

Quadrant A: in this quadrant, shows the attributes that are considered affecting the quality of service satisfaction ratings, but has not been implemented by the management, so that consumers feel less satisfied. These attributes include the availability of bathrooms, employee uniforms, employees answer consumer questions although no intention of buying, there is no fear of being cheated by the seller, employees serve well, employees are willing to look for what is required by customers, employees give an explanation to the patient, the location of the market traditionally close to the residence.

Quadrant B: shows the attributes that need to be maintained or enhanced. In this quadrant level of performance has given satisfaction to the consumer. The attributes in this quadrant is cleanliness maintained, the bathrooms are clean, spacious and safe parking, the calculation of the price is always right, consumers can compare prices freely, the products sold are guaranteed quality, the products sold are safe for consumption, the modern market place close to the residence.

Quadrant $\boldsymbol{C}$ : denotes attributes that have a level of importance and low satisfaction. Attributes in this quadrant are less important to consumers. The attributes include employee clothing, and the state of the market.

\section{Analysis of Performance Matrix Traditional Market Analysis}

Based on the results of questionnaires plot for quality of service and expectations of traditional markets, turns 17 instruments of 18 instruments are in quadrant D that is excessive and should be reduced priority. Given the level of expectation like this, the possibility that there are not too hopeful consumers will increase the performance of traditional markets.

Table 1 Modern Market Performance of Services Quality Aspects

\begin{tabular}{|c|c|c|c|c|c|c|c|c|}
\hline \multirow{2}{*}{ Instrument } & \multicolumn{2}{|c|}{ VNI } & \multicolumn{2}{|c|}{ NI } & \multicolumn{2}{|c|}{ I } & \multicolumn{2}{|c|}{ VI } \\
\hline & $\mathbf{f}$ & $\%$ & f & $\%$ & $\mathbf{f}$ & $\%$ & $\mathbf{f}$ & $\%$ \\
\hline 1. Cleanliness awake & 1 & 2 & 6 & 12 & 19 & 38 & 24 & 48 \\
\hline 2. Bathroom available & 0 & 0 & 2 & 8 & 33 & 66 & 9 & 18 \\
\hline 3. Bathroom cleaner & 1 & 2 & 5 & 10 & 35 & 70 & 9 & 18 \\
\hline 4. Parking area and secure & 0 & 0 & 1 & 2 & 40 & 80 & 9 & 18 \\
\hline 5. Employee well-dressed & 0 & 0 & 9 & 18 & 35 & 70 & 6 & 12 \\
\hline 6. Employees are recognizable by his uniform & 1 & 2 & 6 & 12 & 39 & 78 & 4 & 8 \\
\hline 7. The calculation of the price is always right & 0 & 0 & 9 & 18 & 32 & 64 & 9 & 18 \\
\hline $\begin{array}{l}\text { 8. Employees answered questions consumers though there is no } \\
\text { intention to buy }\end{array}$ & 0 & 0 & 14 & 28 & 31 & 62 & 5 & 10 \\
\hline 9. Consumers can compare prices freely & 0 & 0 & 10 & 20 & 32 & 64 & 8 & 16 \\
\hline 10. The products sold are guaranteed quality & 0 & 0 & 7 & 14 & 34 & 68 & 9 & 18 \\
\hline 11. There is no fear of being cheated by the seller & 0 & 0 & 14 & 28 & 33 & 66 & 3 & 6 \\
\hline 12. The products sold are safe for consumption & 0 & 0 & 8 & 16 & 36 & 72 & 6 & 12 \\
\hline 13. Employees serve well & 0 & 0 & 7 & 14 & 39 & 78 & 4 & 8 \\
\hline 14. Employees willing to look for what consumers need & 0 & 0 & 12 & 24 & 31 & 62 & 7 & 14 \\
\hline 15. Employees explain patiently & 0 & 0 & 14 & 28 & 32 & 64 & 4 & 8 \\
\hline 16. Traditional market near my residence & 2 & 4 & 9 & 18 & 36 & 72 & 3 & 6 \\
\hline 17. 1The modern market is close to my residence & & & 6 & 12 & 41 & 82 & 3 & 6 \\
\hline $\begin{array}{l}\text { 18. Traditional muddy state of the market makes me reluctant to } \\
\text { go there }\end{array}$ & $\begin{array}{l}2 \\
7\end{array}$ & $\begin{array}{l}5 \\
2\end{array}$ & 6 & 12 & 17 & 34 & 1 & 2 \\
\hline
\end{tabular}


This is probably due to hereditary conditions that traditional markets had not been changed, and will always be regarded not been changed.

Instruments to 18 are in quadrant $\mathrm{C}$, which means a low priority. The muddy state of the traditional market, which is not too inconsequential to the consumer because of circumstances like that from time to time.

In general, consumer expectations of service quality traditional markets are not too high because this situation has lasted so long, so that the consumers would be difficult to repair. Consumers are more concerned in terms of the price can be negotiated rather than quality of service. traders who often manipulate the quality and quantity of goods. This further reduces the confidence and interest of consumers to choose the traditional markets as a space fulfillment. This is reinforced by the results of research conducted Business Watch Indonesia (BWI), displacement of traditional markets can be caused by several factors. Among others, lack of infrastructure is good, less comfortable, less expensive capital and on certain products.

Market viability depends on the quality of services related to satisfaction (Logan and Molotch, 1987).

Table 2 Traditional Market Performance of Services Quality Aspects

\begin{tabular}{|c|c|c|c|c|c|c|c|c|c|}
\hline & \multirow{2}{*}{ Instrument } & \multicolumn{2}{|c|}{ VNI } & \multicolumn{2}{|c|}{ NI } & \multicolumn{2}{|c|}{ I } & \multicolumn{2}{|c|}{ VI } \\
\hline & & f & $\%$ & $\mathbf{f}$ & $\%$ & $\mathbf{f}$ & $\%$ & f & $\%$ \\
\hline 1. & Cleanliness awake & 1 & 2 & 9 & 18 & 31 & 62 & 9 & 18 \\
\hline 2. & Bathroom available & 0 & 0 & 15 & 30 & 35 & 70 & 0 & 0 \\
\hline 3. & Bathroom cleaner & 1 & 2 & 13 & 26 & 34 & 68 & 2 & 4 \\
\hline 4. & Parking area and secure & 0 & 0 & 19 & 38 & 25 & 50 & 6 & 12 \\
\hline 5. & Employee well-dressed & 4 & 8 & 21 & 42 & 23 & 46 & 2 & 4 \\
\hline 6. & Employees are recognizable by his uniform & 2 & 4 & 20 & 40 & 27 & 54 & 1 & 2 \\
\hline 7. & The calculation of the price is always right & 0 & 0 & 12 & 24 & 33 & 66 & 5 & 10 \\
\hline 8. & $\begin{array}{l}\text { Employees answered questions consumers though there is no } \\
\text { intention to buy }\end{array}$ & 0 & 0 & 12 & 14 & 36 & 72 & 2 & 4 \\
\hline 9. & Consumers can compare prices freely & 0 & 0 & 15 & 30 & 33 & 66 & 2 & 4 \\
\hline 10. & The products sold are guaranteed quality & 0 & 0 & 16 & 32 & 29 & 58 & 5 & 10 \\
\hline 11. & There is no fear of being cheated by the seller & 1 & 2 & 10 & 20 & 36 & 72 & 3 & 6 \\
\hline 12. & The products sold are safe for consumption & 0 & 0 & 10 & 20 & 36 & 72 & 4 & 8 \\
\hline 13. & Employees serve well & 0 & 0 & 14 & 28 & 33 & 66 & 3 & 6 \\
\hline 14. & Employees willing to look for what consumers need & 0 & 0 & 10 & 20 & 38 & 76 & 2 & 4 \\
\hline 15. & Employees explain patiently & 0 & 0 & 19 & 38 & 29 & 58 & 2 & 4 \\
\hline 16. & Traditional market near my residence & 5 & 10 & 13 & 26 & 30 & 60 & 2 & 4 \\
\hline 17. & 1The modern market is close to my residence & 2 & 4 & 9 & 18 & 35 & 70 & 4 & 8 \\
\hline 18. & $\begin{array}{l}\text { Traditional muddy state of the market makes me reluctant to go } \\
\text { there }\end{array}$ & 39 & 78 & 6 & 12 & 5 & 10 & 0 & 0 \\
\hline
\end{tabular}

\section{Difference Analysis Services Quality/Performance Modern Market and Traditional Market}

From processing the data show that the probability of 0000 , it can be concluded that there is a significant difference between the quality of service/performance of traditional and modern market. This is consistent with findings from qualitative methods showed that the main cause of losing its competitive traditional markets and modern markets is the poor management of traditional markets and traditional markets, poor infrastructure, not solely because of the existence of the modern market. The modern market is actually taking advantage of the bad conditions that exist in traditional markets (Smeru, 2007).
Thresholds market as center of the region depends on the preferences of the population to the type and quality of service (Brown et al, 1993). The distance determines range of services markets and the available modes associated with the costs and benefits. As for the expectations of the visitor market, including the market clean, comfortable, completeness merchandise, and the certainty of operating hours market.

\section{Difference Analysis Layout Modern Market and Traditional Market}

From processing the data show that the probability of 0000 , it was concluded that there is a significant difference between the perceptions of consumers will be the layout of traditional and modern market.

Table 3 Difference Analysis Services Quality / Performance Modern Market and Traditional Market with Independent Sample t-test

\begin{tabular}{|c|c|c|c|c|c|c|c|c|}
\hline & & \multicolumn{7}{|c|}{ t-test for Equality of Means } \\
\hline & & \multicolumn{7}{|c|}{$95 \%$ Confidence Interval of the Difference } \\
\hline & & $\mathrm{t}$ & df & Sig. (2-tailed) & Mean Difference & $\begin{array}{l}\text { Std. Error } \\
\text { Difference }\end{array}$ & Lower & Upper \\
\hline \multirow{2}{*}{$\begin{array}{l}\text { Service } \\
\text { Quality }\end{array}$} & $\begin{array}{l}\text { Equal variances } \\
\text { assumed }\end{array}$ & -4.084 & 98 & .000 & -4.18000 & 1.02360 & -6.21129 & -2.14871 \\
\hline & $\begin{array}{l}\text { Equal variances } \\
\text { not assumed }\end{array}$ & -4.084 & 97.933 & .000 & -4.18000 & 1.02360 & -6.21131 & -2.14869 \\
\hline
\end{tabular}

On the other hand, modern market put forward the concept of professionalism and quality of service to attract consumers as much as possible while the traditional market is synonymous with seedy and squalid conditions. Coupled with the services of
The layout is one of the company's operational functions that will determine the effectiveness and efficiency of company operations. The layout will be related to the utilization of building area. 
Table 3 Difference Analysis of Layout Market and Traditional Market with Independent Sample t-test

\begin{tabular}{|c|c|c|c|c|c|c|c|c|}
\hline & & \multicolumn{7}{|c|}{ t-test for Equality of Means } \\
\hline & & \multicolumn{7}{|c|}{ 95\% Confidence Interval of the Difference } \\
\hline & & $\mathrm{t}$ & $\mathrm{df}$ & Sig. (2-tailed) & $\begin{array}{c}\text { Mean } \\
\text { Difference }\end{array}$ & $\begin{array}{l}\text { Std. Error } \\
\text { Difference }\end{array}$ & Lower & Upper \\
\hline \multirow{2}{*}{ Layout } & $\begin{array}{l}\text { Equal variances } \\
\text { assumed }\end{array}$ & 8.201 & 98 & .000 & 3.60000 & .43900 & 2.72882 & 4.47118 \\
\hline & $\begin{array}{l}\text { Equal variances } \\
\text { not assumed }\end{array}$ & 8.201 & 95.724 & .000 & 3.60000 & .43900 & 2.72857 & 4.47143 \\
\hline
\end{tabular}

In general, modern market in terms of layout design of the building has since been considering the alignment and comfort, with parking provision, a comfortable space, ease of access to public transport, sorting of goods and services from the saleswoman very indulgent consumers. In contrast to the traditional markets that cannot be laid out well, as managers try to maximize the minimum space to accommodate multiple sellers. This is due to venture far to the emergence of many illegal sellers who are outside the traditional market area is allowed. Modern market manager will not be too many have problems because there is only one manager only. While traditional markets to manage a lot of traders in the market environment.

The market will develop appropriate thresholds and the range of services and competition between markets is strongly influenced by public policy, including spatial planning (Glasson, 1978). This shows that the market developments associated with the sustainability of the market must be protected so that optimal investment grant of return.

Judging from the layout, the modern market is more comfortable because the area is spacious and comfortable, the arrangement of items more organized and easily searchable making it easier for consumers to search for necessary goods, clean and does not tarnish with air-conditioning facilities. In contrast to traditional markets memorable shabby, untidy arrangement, the distance between the stalls that is too narrow for passing shoppers, and muddy. From the price, consumers often have to bid to get the best price.

\section{Analysis of the layout of traditional and modern market}

Referring to the image layout modern market, it can be seen that the modern market is more orderly, clean, and comfortable and the service provided is able to satisfy the consumer. The distance between the rack width (approximately 2.8 meters) making consumers more freedom to move, though, pushing the trolley. Goods shelves are organized by type of goods, eg instant noodles, are arranged on a shelf making it easier for consumers to choose and compare the prices of goods. As noted Lila Bismala (2012), the layout of the retail tried to show products as much as possible to its customers, that the preparation of the goods should show a wide variety of brands and prices to be considered by consumers. The management provides the cashier with a large number, so it will not make it too long queues, especially at rush hour. This regularity can be understood as modern market management (hypermart) is one, so it's easy to coordinate and settings.

In contrast to the modern market, the traditional market has been famous since ancient its dirty. This is why traditional market lately abandoned by consumers.
Irregularities cause consumers to feel less comfortable shopping, coupled with state of the muddy and hot. Distance between gang / seller really is not too narrow, but sometimes consumer traffic traffic mixes with merchants who brought a wagon, causing traffic jams. Nice layout will produce a flow of information, goods and better people and interaction with customers better (Lila Bismala, 2012), this is not shown by the layout of the traditional market. The arrangement is not good, mixed all kinds of goods, in addition to causing muddy floor (combined fishmonger with a cloth, vegetables, etc.) also cause markets to smell bad. This is understandable, since the traditional market consists of various sellers, diverse backgrounds that it is difficult to make arrangements and supervisions

\section{CONLUSSION AND RECOMMENDATION}

Customer satisfaction with service quality modern market considered good while customer satisfaction with service quality traditional markets categorized quite good. In addition this study also showed a significant difference between the quality of service / performance of traditional and modern market and there is a significant difference between the perceptions of consumers will be the layout of traditional and modern market. The government should be more concerned with the existence of traditional markets were deemed to be under threat from modern retail is growing rapidly. The government's role here is needed to set up and maintain the balance of competition exist, particularly between the traditional with the modern retail. The government should also improve service to the community, especially the traditional market traders who felt its existence threatened by the presence of modern retail. Things that should be done by the government is a) facilitate access to capital loan assistance for traditional markets in order to expand the business; b) the government should pay more attention to traditional markets, namely in the case where traders sell traditional market and in terms of permitting the entry of Modern Retail; c) improvement of health infrastructure that includes ensuring the proper, adequate sanitation, sufficient light, and overall convenience market environment; d) joint ventures (in the form of employment agreement) between the government and the private sector may also be the best solution to improve the competitiveness of traditional markets; e) the government must curb thugs and extortion or the imposition of existing dark on traditional markets; f) The government should set the distance between traditional and modern market retail far apart, as well as extensive efforts Modern Retail; g) Zoning, i.e. zoning / neighborhood for certain types of retail so as to prevent unequal competition; h) The need for a Law of Retail as the framework and foundation for the government in managing the 
modern retail sector in order to not turn off the traditional markets and maximizing the contribution of modern retail in the local economy is needed.

\section{References}

Brown, T. J., Churchill Jr, G. A. \& Peter, J. P. 1993. Improving the measurement of service quality. Journal of Retailing, 69(1): 127-139.

Devi, L.V Ratna. 2012. Revitalisasi Pasar Tradisional pada Masyarakat Modern. Available at: http://devisakuntala. blogspot.com/2012/03/revitalisasi- pasar-tradisional-pada. html diakses pada tanggal 7 Desember 2012.

Djojodipuro, Marsudi. 1992. Teori Lokasi. Jakarta: LPFE-UI, Jakarta.

Engel, James. Blackwell, Roger. Miniard, Paul. Consumer Behaviour, $9^{\text {th }}$ ed. 2001

Glasson, J 1978. An Intriduction to Regional Planning: Concepts, Theory and Practice, Hutchinson \& Co. (Publishers) Ltd, London.

Lila Bismala, 2012, Manajemen Produksi Operasi, Perdana Publishing, Medan

Logan, John R., and Harvey L. Molotch. 1987. Urban Fortunes: The Political Economy of Place. University of California Press.

Fox, Edward J dan Raj Sethuraman. 2006. "Retail Price Competition”. Retailing in the 21st Century. Halaman 196-208.
Parasuraman, A., V. A. Zeithaml, dan L.L. Berry. 1998. SERVQUAL: A Multiple-Item Scale for Measuring Consumer Perceptions of Service Quality, Journal of Retailing, Vol. 64, No. 1.

Salvatore, Dominick. 2006. Schaum's Outlines: Mikroekonomi. Jakarta: Erlangga

Teller, Christoph dan Thomas Reutterer. 2008. "The Evolving of Retail Attractiveness: What makes Retail Agglomeration Attractive When Customers Shop at Them?". Journal of Retailing and Consumer Behaviour Services, Volume 15. Halaman 127-143.

Thang, Doreen Chze Lin dan Benjamin Lin Boon Tan. 2003. "Linking Consumer Perception to Preference of Retail Stores: an Empirical Assesment of Multi-attributes of Store Image". Journal of Retailing and Consumer Behaviour Services, Volume 10. Halaman 193-200.

Toya, I Nengah. 2012. Pasar Tradisional versus Pasar Modern. Available at: http://diskominfo.Karangase mkab.go.id/index.php/id/artikel/18-pasar-tradisional-versus -pasar-modern diakses pada tanggal 10 Desember 2012.

Weitz, Barton dan Mary Brett Whitfield. 2006. "Trends in US Reatailing". Retailing in the 21st Century. Halaman 59-75.

Zeithaml L, Valerie A. Parasuraman A. Dan Leonard L. Berry. 1990. Delivering Quality Service, Balancing Costumer Perceptions and Expectation. New York: The Free Press.

Zeithaml, Valarie A and Bitner, M.J. Gremler, D.D, 2003. Service Marketing. Edition, Mc Graw-Hill. Singapore.

How to cite this article:

Nel Arianty.2017, Difference analysis of modern market and traditional market strategy based on layout and quality of service. Int J Recent Sci Res. 8(3), pp. 16082-16088. DOI: http://dx.doi.org/10.24327/ijrsr.2017.0803.0071 